\title{
Synthesis and Characterization of Two Cu(II) Nitronyl Nitroxide Complexes
}

\author{
Youjuan Zhang1, Caiwen Zhang'², Jing Chen ${ }^{1,2^{*}}$ \\ ${ }^{1}$ College of Chemistry and Chemical Engineering, Anyang Normal University, Anyang, China \\ ${ }^{2}$ College of Chemistry, Zhengzhou University, Zhengzhou, China \\ Email: ${ }^{\star}$ chenjinghao2008@163.com
}

How to cite this paper: Zhang, Y.J., Zhang, C.W. and Chen, J. (2021) Synthesis and Characterization of Two $\mathrm{Cu}(\mathrm{II}) \mathrm{Ni}$ tronyl Nitroxide Complexes. Open Journal of Inorganic Chemistry, 11, 55-62. https://doi.org/10.4236/ojic.2021.113004

Received: March 22, 2021

Accepted: June 12, 2021

Published: June 15, 2021

Copyright $\odot 2021$ by author(s) and Scientific Research Publishing Inc. This work is licensed under the Creative Commons Attribution International License (CC BY 4.0).

http://creativecommons.org/licenses/by/4.0/

(c) (i) Open Access

\begin{abstract}
Two new nitronyl nitroxide $\mathrm{Cu}(\mathrm{II})$ complexes $\left\{\left[\mathrm{Cu}(\mathrm{hfac})_{2}\right]_{2}(\mathrm{NIT}-4 \mathrm{PyPh})\right\}_{2}(\mathbf{1})$ and $\left[\mathrm{Cu}(\mathrm{hfac})_{2}\right]\left[(\mathrm{NIT}-3 \mathrm{PyPh})_{2}\right](2)(\mathrm{NIT}-4 \mathrm{PyPh}=2-[4-(4-$ pyridinylmethoxy) phenyl]-4,4,5,5-tetramethylimidazoline-1-oxyl-3-oxide,NIT-3PyPh=2-[4-(3-p yridinylmethoxy)phenyl]-4,4,5,5-tetramethylimidazoline-1-oxyl-3-oxide,hfac $=$ hexafluoroacetylacetone), have been synthesized and characterized. The $\mathrm{X}$-ray crystal structure analyses show that structures of the two complexes are different. Complex 1 crystallizes in cyclic metal-radical dimer consisting of four $\mathrm{Cu}(\mathrm{hfac})_{2}$ and two NIT-4PyPh ligands; four $\mathrm{Cu}(\mathrm{II})$ atoms adopt two coordinated modes. In the ring, each $\mathrm{Cu}(\mathrm{II})$ ion is hexa-coordinated by four oxygen atoms of two hfac ligands and one oxygen atom (ONCNO) and one nitrogen atom of the pyridinyl group from two different radicals. Outside the ring, each $\mathrm{Cu}(\mathrm{II})$ is penta-coordinated by four oxygen atoms of two hfac ligands and one oxygen atom (ONCNO) from the radical ligand. Complex 2 crystallizes in discrete molecule, while the $\mathrm{Cu}(\mathrm{II})$ atom is hexa-coordinated by four oxygen atoms of two hfac molecules and two nitrogen atoms of the pyridinyl group from two radical ligands.
\end{abstract}

\section{Keywords}

Nitronyl Nitroxide, Copper Complex, Cyclic Metal-Radical, Synthesis, Characterization

\section{Introduction}

Recently, the combination of metal ions and nitronyl nitroxides has proved to be particularly efficient for making molecular magnetic materials [1] [2]. Because they bear one or more unpaired electrons in their $\pi$-system arising from the overlap between $2 p$ atomic orbitals, stable radicals have rapidly recognized as interesting building blocks for molecule-based magnetic materials. Nitronyl ni- 
troxide (2-(R)-4,4,5,5-tetramethyl-4,5-dihydro-1H-imidazol-1-oxy-3-oxide, NITR) radicals, as excellent spin carriers have played an important role in the design and synthesis of molecular magnetic materials due to their good stability under ambient conditions and easy to modify [3]. Up to now, more and more attention has been paid to design functional radicals to get complexes possessing various kinds of topological structures [4] [5] [6] [7] [8]. However, the N-O groups of nitronyl nitroxide radicals have poor ability to coordinate, thus they only ligate to metal centers with electron with-drawing groups such as hexafluoroacetylacetonate (hfac) and pentafluoropropionic acid (pfpr). Copper(II) complexes are ease to show various kinds of topological structures and are as an unique objects $(s=1 / 2)$ for studying the peculiarities of magnetic exchange pathways between different types of paramagnetic centers, so the syntheses of copper (II)-NITR complexes draw more attentions [4] [9] [10]. Following the research approach, we carried on the syntheses of new functional organic-radical, and prepared $\mathrm{Cu}$-radical complexes. In this paper, two new nitronyl nitroxide $\mathrm{Cu}(\mathrm{II})$ complexes $\left\{\left[\mathrm{Cu}(\mathrm{hfac})_{2}\right]_{2}(\mathrm{NIT}-4 \mathrm{PyPh})\right\}_{2}(1)$ and $\left[\mathrm{Cu}(\mathrm{hfac})_{2}(\mathrm{NIT}-3 \mathrm{PyPh})_{2}\right](2)$ (hfac=hexafluoroacetylacetone) were synthesized and characterized.

\section{Experimental}

\subsection{Materials and Measurements}

All chemicals and solvents used for the syntheses were of reagent grade and were used without further purification. The radical ligands [11] [12] and $\mathrm{Cu}(\mathrm{hfac})_{2} \cdot \mathrm{H}_{2} \mathrm{O}$ have been performed according to the literature methods. All reactions were conducted in aerobic conditions. Elemental analyses for carbon, hydrogen, and nitrogen were carried out on a Model 240 Perkin-Elmer elemental analyzer. Infrared spectra were taken on a Bruker Tensor 27 Fourier transform infrared spectroscopy in the region $4000-400 \mathrm{~cm}^{-1}$, using $\mathrm{KBr}$ pellets. Ultraviolet-visible spectra were recorded on a Cary $50 \mathrm{UV}$-Vis spectrophotometer in stated solvent.

\subsection{Synthesis of $\left\{\left[\mathrm{Cu}(\mathrm{hfac})_{2}\right]_{2}(\mathrm{NIT}-4 \mathrm{PyPh})\right\}_{2}(1)$}

$\mathrm{Cu}(\mathrm{hfac})_{2} \cdot 2 \mathrm{H}_{2} \mathrm{O}(0.01 \mathrm{mmol})$ was refluxed at $85^{\circ} \mathrm{C}$ for 30 minutes in $20 \mathrm{~mL}$ $\mathrm{n}$-heptane. Then the reactant was cooled to $60^{\circ} \mathrm{C}, 6 \mathrm{~mL}$ of dichloromethane solution containing $0.01 \mathrm{mmol}$ 4-pyridinephenyl nitroxide radical (NIT-4PyPh) was added, and stirring was continued for 15 minutes. Then, it was cooled to the room temperature, and filtered. One week later, block deep-blue crystals suitable for single crystal diffraction had been obtained. Anal. Calcd. (\%) for $\mathrm{C}_{78} \mathrm{H}_{52} \mathrm{Cu}_{4} \mathrm{~F}_{48} \mathrm{~N}_{6} \mathrm{O}_{22}$ (2591.46): C, 36.15; N, 3.24; H, 2.02; Found: C, 36.33; N, 3.12; H, 1.91\%. FTIR (KBr, cm $\left.{ }^{-1}\right): 1644$ (s), 1524 (s), 1499 (m), 1465 (m), 1363 (m), 1255 (s), 1198 (s), 1138 (s), 795 (m), $586(\mathrm{~m})$. UV-Vis (nm): 294 and $395 \mathrm{~nm}$.

\subsection{Synthesis of $\left\{\left[\mathrm{Cu}(\mathrm{hfac})_{2}\right](\mathrm{NIT}-3 \mathrm{PyPh})_{2}\right\}(2)$}

$\mathrm{Cu}(\mathrm{hfac})_{2} \cdot 2 \mathrm{H}_{2} \mathrm{O}(0.01 \mathrm{mmol})$ was refluxed at $85^{\circ} \mathrm{C}$ for 30 minutes in $15 \mathrm{~mL}$ 
$\mathrm{n}$-heptane. Then the reactant was cooled to $70^{\circ} \mathrm{C}, 5 \mathrm{~mL}$ of dichloromethane solution containing $0.02 \mathrm{mmoL}$ 3-pyridinephenyl nitroxide radical (NIT-3PyPh) was added, and stirring was continued for $30 \mathrm{~min}$. Then, it was cooled to the room temperature, and filtered. A few days later, Flake blue crystals suitable for single crystal diffraction had been obtained. Anal. Calcd. (\%) for $\mathrm{C}_{48} \mathrm{H}_{46} \mathrm{CuF}_{12} \mathrm{~N}_{6} \mathrm{O}_{10}(1158.46): \mathrm{C}, 49.76 ; \mathrm{H}, 4.00$; N, 7.25; Found: C, 49.87; H, 3.75; N, 7.14\%. FTIR (KBr, cm $\left.{ }^{-1}\right): 1653$ (m), 1550 (s), 1364 (m), 1253 (s), 1188 (s), 795 (m), $668(\mathrm{~m})$. UV-Vis (nm): 283, 363 and $606 \mathrm{~nm}$.

\subsection{X-Ray Crystallography}

The diffraction data were collected at $150 \mathrm{~K}$ with Mo-Ka $(\lambda=0.71073 \AA)$ radiation using a Bruker CCD APEX-II diffractometer. The structures were solved by direct methods and refined by full-matrix least-squares methods on $\mathrm{F}^{2}$ by using the SHELXL-97 program package [13]. Empirical absorption corrections from $\varphi$ and $\omega$ scan were applied. All non-hydrogen atoms were refined anisotropically, and all hydrogen atoms were added theoretically. Crystal parameters, data collection procedure, and refinement results for complexes 1-2 are summarized in detail in Table 1. Selected bond lengths and angles for the two complexes are listed in Table 2.

Table 1. Crystallographic data and structure refinement details for 1-2.

\begin{tabular}{|c|c|c|}
\hline Complex & $\left\{\left[\mathrm{Cu}(\mathrm{hfac})_{2}\right]_{2}(\mathrm{NIT}-4 \mathrm{PyPh})\right\}_{2}(1)$ & {$\left[\mathrm{Cu}(\mathrm{hfac})_{2}(\mathrm{NIT}-3 \mathrm{PyPh})_{2}\right](2)$} \\
\hline Empirical formula & $\mathrm{C}_{78} \mathrm{H}_{52} \mathrm{Cu}_{4} \mathrm{~F}_{48} \mathrm{~N}_{6} \mathrm{O}_{22}$ & $\mathrm{C}_{48} \mathrm{H}_{46} \mathrm{CuF}_{12} \mathrm{~N}_{6} \mathrm{O}_{10}$ \\
\hline Temperature/K & 150 & 150 \\
\hline Formula weight & 2591.46 & 1158.46 \\
\hline Crystal system & Triclinic & Monoclinic \\
\hline Space group & P-1 & $\mathrm{P} 2_{1} / \mathrm{n}$ \\
\hline \multicolumn{3}{|l|}{ Unit cell dimensions } \\
\hline $\mathrm{a} / \AA ̊$ & $11.0090(4)$ & $6.4620(2)$ \\
\hline $\mathrm{b} / \AA$ & $12.2619(5)$ & $11.6521(3)$ \\
\hline$c / \AA$ & $18.6132(7)$ & $33.2897(9)$ \\
\hline$\alpha l^{\circ}$ & $86.910(1)$ & 90 \\
\hline$\beta 1^{\circ}$ & $75.598(1)$ & $93.848(1)$ \\
\hline$\gamma 1^{\circ}$ & $85.050(1)$ & 90 \\
\hline Volume $/ \AA^{3}$ & $2423.21(16)$ & $2500.93(12)$ \\
\hline $\mathrm{Z}$ & 1 & 2 \\
\hline Calculated density $\left(\mathrm{Mg} / \mathrm{m}^{3}\right)$ & 1.776 & 1.538 \\
\hline Absorption coeffificient $\left(\mathrm{mm}^{-1}\right)$ & 1.030 & 0.546 \\
\hline $\mathrm{F}(000)$ & 1286.0 & 1186.0 \\
\hline Crystal size $\left(\mathrm{mm}^{3}\right)$ & $0.12 \times 0.11 \times 0.09$ & $0.21 \times 0.12 \times 0.09$ \\
\hline$\theta$ range for data collection $\left({ }^{\circ}\right)$ & $2.26-28.32$ & $2.14-28.32$ \\
\hline
\end{tabular}




\section{Continued}

Limiting indices

Reflflections collected/unique

$$
\text { R (int) }
$$

Data/restraints/parameters

Final $\mathrm{R}$ indices $[\mathrm{I}>2 \sigma(\mathrm{I})]$

$\mathrm{R}$ indices (all data)

Largest diff. peak and hole
$-14 \leq \mathrm{h} \leq 14,-16 \leq \mathrm{k} \leq 16,-24 \leq 1 \leq 24$

$48,453 / 12,047$

0.0658

$12,047 / 0 / 712$

$\mathrm{R}_{1}=0.0679, \mathrm{wR}_{2}=0.1547$

$\mathrm{R}_{1}=0.1163, \mathrm{wR}_{2}=0.1840$

1.857 and -0.995 e. $\mathrm{A}^{-3}$
$-8 \mathrm{~h} \leq \mathrm{h} \leq 8,-15 \leq \mathrm{k} \leq 15,-44 \leq 1 \leq 39$

$20,312 / 6222$

0.0434

$6222 / 0 / 349$

$\mathrm{R}_{1}=0.0437, \mathrm{wR}_{2}=0.1010$

$\mathrm{R}_{1}=0.0652, \mathrm{wR}_{2}=0.1146$

0.558 and -0.457 e. $\mathrm{A}^{-3}$

Table 2. Crystallographic data and structure refinement details for 1-2.

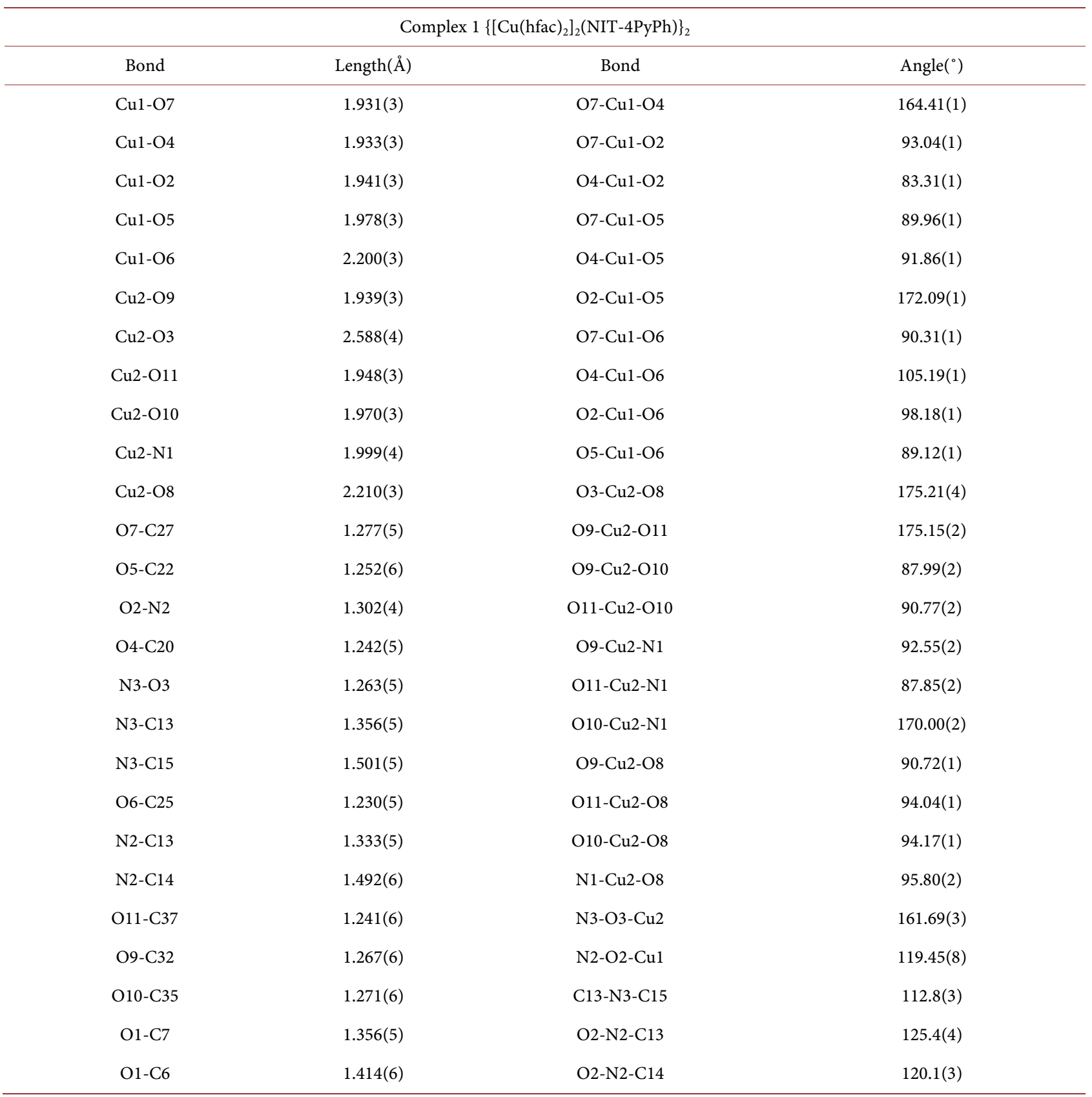




\begin{tabular}{|c|c|c|c|}
\hline N1-C1 & $1.336(6)$ & C13-N2-C14 & $113.8(3)$ \\
\hline N1-C5 & $1.338(6)$ & C7-O1-C6 & $121.2(4)$ \\
\hline $\mathrm{O} 8-\mathrm{C} 30$ & $1.227(6)$ & $\mathrm{N} 2-\mathrm{C} 13-\mathrm{N} 3$ & $107.1(4)$ \\
\hline \multicolumn{4}{|c|}{ Complex $2\left[\mathrm{Cu}(\mathrm{hfac})_{2}(\mathrm{NIT}-3 \mathrm{PyPh})_{2}\right]$} \\
\hline Bond & Length $(\AA)$ & Bond & Angle $\left({ }^{\circ}\right)$ \\
\hline $\mathrm{Cu} 1-\mathrm{O} 4$ & $1.9733(14)$ & $\mathrm{O} 4-\mathrm{Cu} 1-\mathrm{N1}^{\#}$ & $89.71(6)$ \\
\hline Cu1-N1 & $2.0589(17)$ & O4-Cu1-N1 & $90.30(6)$ \\
\hline $\mathrm{Cu} 1-\mathrm{O} 5$ & $2.2802(15)$ & $\mathrm{O} 4^{\#-C u 1-N 1}$ & $90.29(6)$ \\
\hline N1-C3 & $1.344(3)$ & $\mathrm{O} 4^{\#}-\mathrm{Cu} 1-\mathrm{N} 1^{\#}$ & $89.70(6)$ \\
\hline N1-C2 & $1.346(3)$ & $\mathrm{N} 1-\mathrm{Cu} 1-\mathrm{N} 1^{\#}$ & $180.00(9)$ \\
\hline $\mathrm{N} 3-\mathrm{O} 2$ & $1.273(2)$ & $\mathrm{O} 4-\mathrm{Cu} 1-\mathrm{O} 5$ & $87.17(6)$ \\
\hline N3-C13 & $1.353(3)$ & $\mathrm{N} 1-\mathrm{Cu} 1-\mathrm{O}^{\#}$ & $87.96(6)$ \\
\hline N3-C15 & $1.495(3)$ & N1-Cu1-O5 & $92.04(6)$ \\
\hline $\mathrm{O} 3-\mathrm{C} 7$ & $1.363(3)$ & O5-Cu1-O5 & $180.00(7)$ \\
\hline O3-C6 & $1.432(3)$ & C3-N1-C2 & $117.09(2)$ \\
\hline $\mathrm{O} 1-\mathrm{N} 2$ & $1.278(2)$ & $\mathrm{O} 2-\mathrm{N} 3-\mathrm{C} 13$ & $126.9(2)$ \\
\hline $\mathrm{N} 2-\mathrm{C} 13$ & $1.356(3)$ & $\mathrm{O} 2-\mathrm{N} 3-\mathrm{C} 15$ & $121.36(2)$ \\
\hline N2-C14 & $1.504(3)$ & C13-N3-C15 & $111.67(2)$ \\
\hline $\mathrm{C} 22-\mathrm{O} 5$ & $1.233(2)$ & $\mathrm{C} 7-\mathrm{O} 3-\mathrm{C} 6$ & $118.47(2)$ \\
\hline
\end{tabular}

\section{Results and Discussion}

\subsection{Crystal Structure}

\subsubsection{The Complex $\left\{\left[\mathrm{Cu}(\mathrm{hfac})_{2}\right]_{2}(\mathrm{NIT}-4 \mathrm{PyPh})\right\}_{2}(1)$}

The perspective view of the molecular structure of the complex 1 is illustrated in Figure 1. The important bond lengths and angles are displayed in Table 2. Single-crystal X-ray analysis reveals that the molecular structure of the complex $\left\{\left[\mathrm{Cu}(\mathrm{hfac})_{2}\right]_{2}[(\mathrm{NIT}-4 \mathrm{PyPh})]\right\}_{2}(1)$ crystallizes in the Triclinic space group P-1 and is central symmetric. Two NIT-4PyPh radical ligands are coordinated to four $\mathrm{Cu}$ (II) ions through the oxygen atoms of the nitronyl nitroxide groups and the nitrogen atoms of the pyridine rings in cis-configuration to form a six-spin cyclic complex. Every NIT-4PyPh ligand serves as a bridge to connect two $\mathrm{Cu}(\mathrm{II})$ centers via its one nitroxide and one pyridine ring to form centro-symmetric dimeric cycle $[\mathrm{Cu}-(\mathrm{NIT}-4 \mathrm{PyPh})]_{2}$. Each NIT-4PyPh radical links three different copper(II) ions through the oxygen of nitroxide group and the pyridyl nitrogen to form the cyclic six spin unit. In the unit, four $\mathrm{Cu}$ (II) atoms adopt two coordinated modes. In the ring, each $\mathrm{Cu}(\mathrm{II})$ ion is hexa-coordinated by four oxygen atoms of two hfac ligands and by one oxygen atom and one nitrogen atom of the pyridinyl group from two different radicals. Outside the ring, each $\mathrm{Cu}(\mathrm{II})$ is penta-coordinated by four oxygen atoms of two hfac ligands and by one oxygen atom from the radical. 


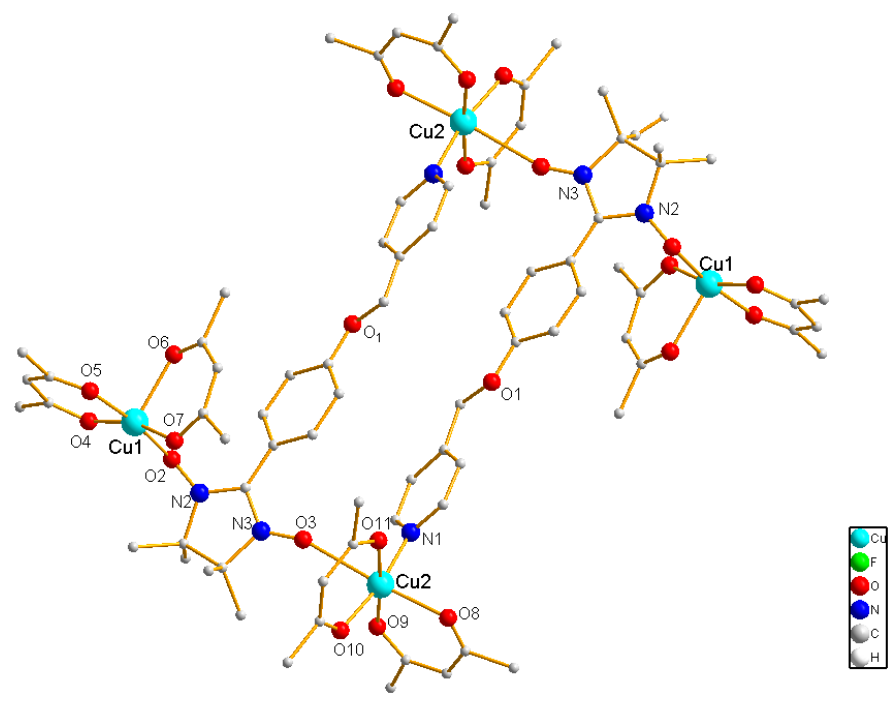

Figure 1. The molecular structure of complex 1. Hydrogen and Fluorine atoms are not shown for the sake of clarity.

In the ring, the $\mathrm{Cu}(\mathrm{II})$ ion is hexa-coordinated; the $\mathrm{Cu}-\mathrm{N}$ and $\mathrm{Cu}-\mathrm{O}$ (nitroxide group) bond lengths are 1.999(4) and 2.588(4) $\AA$, respectively. The bond lengths of the $\mathrm{Cu}-\mathrm{O}(\mathrm{hfac})$ are in the range of $1.939(3)-2.210(3) \AA$ and the $\mathrm{Cu}-\mathrm{O}-\mathrm{N}$ angles are $161.69(3)$, which are comparable to those of reported $\mathrm{Cu}(\mathrm{hfac})_{2}$ complexes with nitronyl nitroxides [14]. Outside the ring, the $\mathrm{Cu}(\mathrm{II})$ ion is penta-coordinated; the $\mathrm{Cu}-\mathrm{O}$ (nitroxide group) bond lengths are 1.941(3) $\AA$. The bond lengths of the $\mathrm{Cu}-\mathrm{O}(\mathrm{hfac})$ are in the range of 1.931(3) - 2.200(3) $\AA$. The $\mathrm{Cu}-\mathrm{O}-\mathrm{N}$ angles are 119.45(8). In the six-spin cyclic complex unit, the radical ligand should be considered as a tridentate ligands, while two oxygen atom (nitroxide group) and nitrogen atom (pyridine ring) of the same NIT-4-PyPh radical ligand directly coordinated with three different $\mathrm{Cu}(\mathrm{II})$ ions. The benzene ring of nitronyl nitroxide has a dihedral angle of $33.1^{\circ}$ with the ONCNO five member ring. The pyridine ring of nitronyl nitroxide has a dihedral angle of $81.3^{\circ}$ with the average plane consisting of equatorial oxygen atoms of the hfac ligands and the $\mathrm{Cu}_{2}$ atom. The dihedral angle is $43.1^{\circ}$ between the ONCNO five member and the average plane consisting of equatorial oxygen atoms of the hfac ligands bonding with the $\mathrm{Cu} 1$ atom. It is noticed that weak coordination bonds are formed between the $\mathrm{Cu} 2$ of $\mathrm{Cu}(\mathrm{hfac})_{2}$ and the $\mathrm{O} 3$ atoms of nitronyl nitroxide with the oxygen atoms occupying the apical positions. The weak $\mathrm{Cu} 2-\mathrm{O} 3$ bond length is 2.588(4) $\AA$, and the bond angle of N3-O3-Cu2 is 161(7). Here, we could consider $\mathrm{ONCNO}$ as a bidentate bridged two different $\mathrm{Cu}(\mathrm{hfac})_{2}$ units.

\subsubsection{The Complex [Cu(hfac $\left.)_{2}(\mathrm{NIT}-3 \mathrm{PyPh})_{2}\right](2)$}

A view of the molecular structure of complex 2 is shown in Figure 2. The important bond lengths and angles are displayed in Table 2. Single-crystal X-ray analysis reveals that complex 2 crystallizes in the monoclinic space group $\mathrm{P}_{1} / \mathrm{n}$. The NIT-3PyPh ligand constructed based on the "head to head" motif. The coordination unit of complex 2 is $\mathrm{CuN}_{2} \mathrm{O}_{4}, \mathrm{Cu}$ (II) ion exhibited as octahedron 


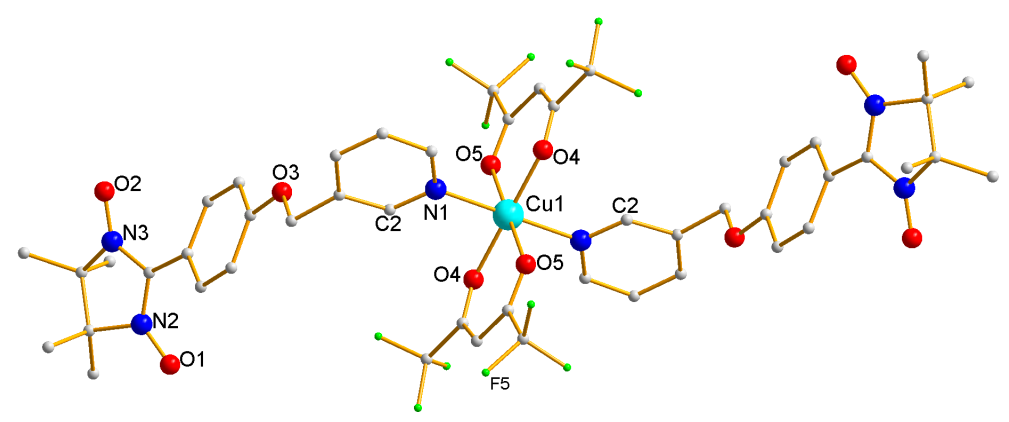

Figure 2. Simplified view of the crystal structures of compound 2.

configuration. $\mathrm{Cu}(\mathrm{II})$ center is defined by two nitrogen atoms and four oxygen atoms coming from pyridine rings of radicals and $\beta$-diketonate coligands, respectively. The equatorial $\mathrm{Cu}-\mathrm{O}_{\text {hfac }}$ bond lengths are 1.973(3) - 2.280(2) $\AA$. The apical sites are filled with two $\mathrm{N}$ atoms of two radical ligands, and $\mathrm{Cu}-\mathrm{N}$ bond distance is 2.058(9) $\AA$. The nitronyl groups on the two radicals are uncoordinated.

\section{Conclusion}

Two new Cu-Radial complexes have been synthesized, and characterized by $\mathrm{X}$-ray single crystal diffraction, elemental analysis, infrared spectroscopy and Uv-Vis spectroscopy. The analysis results indicated that complex 1 display an interesting cyclic dimers, whereas, the complex 2 exhibit a discrete molecule and two $\mathrm{N}$ atoms (-pyridyl group) of two radical ligands. The magnetic properties of the two complexes 1-2 are under researching.

\section{Conflicts of Interest}

The authors declare no conflicts of interest regarding the publication of this paper.

\section{References}

[1] Ratera, I. and Vecian, J. (2012) Playing with Organic Radicals as Building Blocks for Functional Molecular Materials. Chemical Society Reviews, 41, 303-349. https://doi.org/10.1039/C1CS15165G

[2] Meng, X.X., Shi, W. and Cheng, P. (2019) Magnetism in One-Dimensional Metal-Nitronyl Nitroxide Radical System. Coordination Chemistry Reviews, 378, 134-150. https://doi.org/10.1016/j.ccr.2018.02.002

[3] Train, C., Norel, L. and Baumgarten, M. (2009) Organic Radicals, a Promising Route towards Original Molecule-Based Magnetic Materials. Coordination Chemistry Reviews, 253, 2342-2351. https://doi.org/10.1016/j.ccr.2008.10.004

[4] Sherstobitova, T., Maryunina, K., Tolstikov, S., Letyagin, G., Romanenko, G., Nishihara, S. and Inoue, K. (2019) Ligand Structure Effects on Molecular Assembly and Magnetic Properties of Copper(II) Complexes with 3-Pyridyl-Substituted Nitronyl Nitroxide Derivatives. ACS Omega, 4, 17160-17170. https://doi.org/10.1021/acsomega.9b01575

[5] Shi, J.Y., Ma, Z.L., Wang, M.C. and Tian, L. (2021) A Family of 2p-3d Complexes 
Based on 4,5-Dimethyltriazole Nitronyl Nitroxide Radical: Synthesis, Structure, and Magnetic Properties. Inorganica Chimica Acta, 516, 120-122. https://doi.org/10.1016/j.ica.2020.120122

[6] Sun, J., Wang, K., Jing, P., Lu, J. and Li, L.C. (2019) 2p-3d-4f Heterotrispin Chains and Ring-Chains Bridged by a Nitronyl Nitroxide Ligand: Structure and Magnetic Properties. Crystal Growth \& Design, 19, 3576-3583.

https://doi.org/10.1021/acs.cgd.9b00489

[7] Li, C., Li, H.D., Xie, J., Yang, M., Wang, X.F. and Li, L.C. (2018) $\left\{\left[\operatorname{Ln}(\mathrm{hfac})_{3}\right]_{2}\left[\mathrm{Cu}(\mathrm{hfac})_{2}\right]_{3}(\mathrm{NIT}-\mathrm{Pyrim})_{2}\left(\mathrm{H}_{2} \mathrm{O}\right)_{2}\right\}\left(\operatorname{Ln}^{\mathrm{III}}=\mathrm{Gd}, \mathrm{Ho}, \mathrm{Er}\right)$ : Unique Nitronyl Nitroxide Bridged 3d-4f Heterometallic Clusters. Chemistry Europe, 2018, 525-530. https://doi.org/10.1002/ejic.201700576

[8] Calancea, S., Carrella, L., Mocanu, T., Sadohin, V., Raduca, M., Gutu, L., Rocha, J.C., Vaz, M.G.F., Rentschler, E. and Andruh, M. (2021) Magnetic Molecular Rectangles Constructed from Functionalized Nitronyl-Nitroxide Ligands and Lanthanide(III) Ions. Chemistry Europe, 2021, 567-577. https://doi.org/10.1002/ejic.202000954

[9] Gao, Y.L. and Inoue, K. (2020) Synthesis, Crystal Structures and Magnetic Properties of Nitronyl Nitroxide Radical-Coordinated Copper(II) Complexes. Transition Metal Chemistry, 45, 195-201. https://doi.org/10.1007/s11243-019-00370-y

[10] Yang, M., Xie, S.F., Liang, X.H., Zhang, Y.D. and Dong, W. (2019) A Novel Nitronyl Nitroxide and Its Copper Complexes: Synthesis, Structures and Magnetic Properties. Inorganica Chimica Acta, 486,589-593. https://doi.org/10.1016/j.ica.2018.10.031

[11] Zhu, M., Yang, M., Wang, J.J., Li, H.D. and Li, L.C. (2016) Structural and Magnetic Properties of 2p-3d-4f Hetero-Tri-Spin Chains Comprising [ $\left.\left\{\mathrm{Cu}(\mathrm{hfac})_{2} \text {-Radical }\right\}_{2}\right]$ Dimers and $\operatorname{Ln}(\mathrm{hfac})_{3}$ (hfac=hexafluoroacetylacetonate). Chemistry. An Asian Journal, 11, 1900-1905. https://doi.org/10.1002/asia.201600383

[12] Ullman, E.F., Call, L. and Osiecki, J.H. (1970) Stable Free Radicals. VIII. New Imino, Amidino, and Carbamoyl Nitroxides. The Journal of Organic Chemistry, 35, 3623-3631. https://doi.org/10.1021/jo00836a008

[13] Sheldrick, G.M. (1997) SHELXS-97, Program for Crystal Structure Solution. University of Göttingen, Germany.

[14] Wang, X.F., Hu, P., Li, L.C. and Sutter, J.P. (2015) [(Cu-Radical) $)_{2}-\mathrm{Ln}$ ]: Structure and Magnetic Properties of a Hetero-Trispin Chain of Rings ( $\mathrm{Ln}=\mathrm{Y}^{\mathrm{III}}, \mathrm{Gd}^{\mathrm{III}}, \mathrm{Tb}^{\mathrm{III}}$, Dy ${ }^{\mathrm{III}}$ ). Inorganic Chemistry, 54, 9664-9669.

https://doi.org/10.1021/acs.inorgchem.5b01761 